5 Donnelly RJ, Page RD, Cowen ME. Endoscopy assisted microthoracotomy: initial experience. Thorax 1992;47: 490-3.

6 Ginsberg RJ, Rubinstein L. A randomized comparative trial of lobectomy vs segmentectomy for patients with T1 N0 non-SCLC lung cancer. Lung Cancer 1991; 7(Suppl):83A

7 Warren WH, Faber LP. Segmentectomy versus lobectomy in patients with stage I pulmonary carcinoma. $\mathcal{F}$ Thorac

8 Ichinose Y, Yano T, Yokoyama $\mathrm{H}$, Inoue $\mathrm{T}$, Asoh $\mathrm{H}$, Katsuda Y. The correlation between tumor size and lymphatic vessel invasion in resected peripheral stage I non-small cell lung cancer. $f$ Thorac Cardiovasc Surg 1994;108:684-6.

9 Kirby TJ, Mack MJ, Landreneau RJ, Rice TW. Initial experience with video-assisted thoracoscopic lobectomy. Ann Thorac Surg 1993;56:1248-53.

10 Walker WS, Carnochan FM, Pugh GC. Thoracoscopic pulmonary lobectomy. $\mathcal{F}$ Thorac Cardiovasc Surg 1993;106 1111-7.

11 Walker WS, Carnochan FM, Tin M. Thoracoscopy assisted pulmonary lobectomy. Thorax 1993;48:921-4.

12 Thurer R. Video-assisted thoracic surgery. Ann Thorac Surg 1993;56:199-200.

13 Nduka CC, Monson JRT, Menzies-Gow N, Darzi A. Abdominal wall metastases following laparoscopy. Br f Surg 1994;81:648-52.

14 Giudicelli R, Thomas P, Lonjon T, Ragni J, Bulgare JC Ottomani $\mathbf{R}$, et al. Major pulmonary resection by video assisted mini-thoracotomy. Eur f Cardiothorac Surg 1994; 8:254-8.

\title{
The Crofton Cup II: non-tobacco sponsored golf goes full strength - players please
}

"I'm looking for the organiser of the golf - it's Ainslie Moore here - I can play you know."

It is the evening before the competition. Tee times confirmed, lists made, dinner for 50 booked, weather prayed for and here on cue is the Reverend Moore.

"Of course. Delighted. See you at the clubhouse."

Dawn breaks, skies not quite as blue as last year and a quality links breeze is lifting the slates. Arran is sitting pretty off to the west and the sea is stunning. Would the golf be difficult? Try playing in a filmset - easier perhaps if Teuton than Celt.

The morning round is played by a favoured few, joined by some locals who had heard of the event and wanted to play in the sweep promptly donated by the winner to the charity.

After lunch the tee is busy with chest physicians, GPs, and a motley bunch from commerce - business people, bankers and accountants. Our worry that this Open qualifier course would be a mite tricky proved marginally correct. The motley bunch did very well though, and $\mathrm{Mr}$ Teuton from the bank won the trophy. Reverend Moore, as predicted, won the ecclesiastical medal, and the physician from Edinburgh choked on his pipe (rarely lit) when a colleague from the West tabled his score of 158 .

"Quite remarkable," as we (including $\mathrm{Dr}$ 158) drowned in ungracious tears of laughter.

That the event was competitive in spirit was acceptable - but we did not expect sequential birdies from the mild mannered GP or the dead heat in the longest drive which, according to the Barassie (now European Club Cham- pions) Secretary, was probably unique in the history of golf - an assessment quite agreeable to the successful young fellow and Dr Pipe from Edinburgh (mutual nodding). Another Dr Pipe (only-lit-when-fishing) took the prize for the par threes and is negotiating his prize with our friendly clubmaker (Macpherson of Troon).

So ended another Crofton Cup. Since we wish to develop our concerns about tobacco sponsorship in golf beyond the Crofton, the Physiks Plate is our UK wide response. Details of this event - for a prize determined by submission of the highest Stableford score under medal conditions at the competitor's own course during June - will be sent out after application and registration (fee $f^{5}$ ) at the Scottish Office of the British Lung Foundation, Royal College of Physicians and Surgeons of Glasgow, 234-242 St Vincent Street, Glasgow G2 5RJ. This will be an open competition, and we seek support from all who are impressed by an obligation to act in favour of tobacco sponsorship-free sport. Although we in the West of Scotland hold the world record for lung cancer, mainly due to the efforts of tobacco, we do so reluctantly. In terms of sporting records at the highest level, distribution is more consistently international and, surprisingly, occurs in the complete absence of tobacco.

On the basis of obtuse rationality, perhaps readers elsewhere in the world might also wish to take part. Players please.

KENNETH ANDERSON 